\title{
SISTEM SELEKSI PENERIMAAN TENAGA KERJA OUTSOURCING MENGGUNAKAN ALGORITMA C5.0 BERBASIS ANDROID (STUDI KASUS : PT. SINERGI INDO PRIMA MEDAN)
}

\author{
${ }^{1)}$ Aryati, ${ }^{2)}$ Samsudin, ${ }^{3)}$ M.Fakhriza \\ ${ }^{1,2,3)}$ Program Studi Sistem Informasi, Fakultas Sains dan Teknologi, Universitas Islam Negeri Sumatera Utara \\ ${ }^{1,2,3)}$ J1. IAIN No.1 - Medan - Indonesia \\ E-mail : aryati.0702163109@uinsu.ac.id, samsudin@uinsu.ac.id,fakhriza@uinsu.ac.id
}

\begin{abstract}
ABSTRAK
PT. Sinergi Indo Prima merupakan perusahaan yang mendukung pelayanan jasa ketenagakerjaan atau disebut dengan istilah outsourcing. Pelayanan jasa yang termasuk dalam outsourcing ialah satpam, staf administrasi, buruh pabrik, supir, sales promotor dan jasa kebersihan. Adapun dalam menemukan calon tenaga kerja PT. Sinergi Indo Prima Medan memiliki kendala sistem masih manual, penginputan data hanya dengan menggunakan Microsoft Excel atau belum memiliki sistem pendukung keputusan yang profesional dalam memilih seorang calon tenaga kerja yang sesuai dengan kriteria persyaratan, sehingga calon tenaga kerja yang akan disalurkan belum sesuai dengan kompetensi bidang keahlian yang dibutuhkan oleh perusahaan yang membutuhkan. Pada penelitian ini penulis penulis menggunakan metode pengembangan Rapid Application Development (RAD), menggunakan Algoritma C5.0, dengan dukungan tools Unified Modelling Language (UML) menggunakan bahasa pemrograman Java berbasis Android Studio, Microsoft Visio dan Umlet untuk mendesain interface. Hasil dari perancangan sistem seleksi penerimaan calon tenaga kerja outsourcing ialah suatu aplikasi yang bernama AKSIP digunakan untuk proses seleksi data calon tenaga kerja pada masing-masing kategori pekerjakan, adapun hasil percobaan data uji dari 6 kategori pekerjaan dengan menggunakan algoritma C5.0 mencapai persentasi nilai akurasi keberhasilan sebesar $94 \%$.
\end{abstract}

Kata Kunci: Algoritma C5.0, Outsourcing, Pohon Keputusan, Rapid Application Development (RAD), Sistem Pendukung Keputusan.

\begin{abstract}
PT. Sinergi Indo Prima is a company that supports employment services or called outsourcing. Services included in the outsourcing are security guards, administrative staff, factory workers, drivers, sales promoters, and cleaning services. As for looking for prospective workers PT. Sinergi Indo Prima Medan has a problem, namely the system is still manual, data input only uses Microsoft Excel or does not have a professional decision support system in selecting prospective workers who meet the criteria, so that the prospective workers to be distributed are not in accordance with the competencies of the areas of expertise assigned to them. required by companies in need. In this study the author uses the Rapid Application Development (RAD) development method, using the C5.0 Algorithm, with the support of Unified Modeling Language (UML) tools using the Java programming language based on Android Studio, Microsoft Visio and Umlet to design the interface. The results of the design of the recruitment selection system for outsourcing prospective workers is an application called AKSIP which is used for the data selection process for prospective workers in each job category, while the results of testing data from 6 job categories using the C5.0 Algorithm achieve a success percentage of accuracy value of $94 \%$.
\end{abstract}

Keyword: C5.0 Algorithm, Outsourcing, Decision Tree, Rapid Application Development (RAD), Decision Support System

\section{PENDAHULUAN}

Perkembangan Teknologi Informasi dapat mempengaruhi produktifitas Sumber Daya Manusia (SDM). Sumber Daya Manusia adalah suatu aset yang sangat mendukung untuk meningkatkan salah satunya kualitas kerja bagi suatu perusahaan, peranan teknologi informasi dalam dunia bisnis salah satunya adalah sistem pendukung keputusan pada penerimaan tenaga kerja, dalam hal ini yang membutuhkan sistem seleksi penerimaan tenaga kerja adalah perusahaan yang bergerak di bidang pelayanan jasa (outsourcing) hal itu karena perusahaan outsourcing perlu melakukan seleksi terhadap calon-calon tenaga kerja yang akan disalurkan atau adanya permintaan bagi suatu perusahaan, sesuai dengan kompetensi bidang keahlian tenaga kerja terhadap perusahaan yang membutuhkan 
pada Undang-Undang Nomor 13 Tahun 2003 tentang ketenagakerjaan outsourcing (ahli daya) ialah dikenal sebagai penyedia jasa tenaga kerja.

Penulisan ini dikembanggkan dari penulisan sebelumnya Hutagaol (2017), dalam perekrutan penerimaan karyawan menggunakan algoritma decision tree dengan menggunakan algoritma C4.5.[1]

Pada penelitian kali ini sistem seleksi penerimaan tenaga kerja outsourcing dengan konsep sistem pendukung keputusan berbasis android dilakukan lebih dari satu atau 6 (enam) profesi pekerjaan dengan menggunakan algoritma C5.0 kelebihan algoritma C5.0 dapat mengklasifikasi kriteria yang dibuat menjadi pohon keputusan lebih cepat dan lebih kecil, membentuk rule yang lebih sederhana atau ringkas, lebih sedikit memakai memory, lebih baik dalam mengetahui tingkat keakuratan data atau akurasi data, serta kelebihannya yang berbasis android membuat sistem pendukung keputusan lebih userfriendly dan praktis untuk di implementasikan.

\section{Sistem Informasi}

Sistem Informasi adalah sekumpulan hardware, software, brainware, prosedur dan atau aturan yang diorganisasikan secara integral untuk mengolah data menjadi informasi yang bermanfaat guna memecahkan masalah dan pengambilan keputusan.[2] [3]

\section{Sistem Pendukung Keputusan}

Little (Turban, 2005) mendefiknisikan Sistem Pendukung Keputusan (SPK) sebagai model dari sekumpulan prosedur untuk melakukan pengolahan data dengan tujuan membantu manajer dalam pembuatan keputusan spesifik. Little berpendapat bahwa penerapan Sistem Pendukung Keputusan (SPK) hanya akan berhasil bila sistem tersebut bersifat sederhana dan mudah digunakan, mudah melakukan pengawasan, mudah melakukan adaptasi terhadap perubahan lingkungan, dan mudah melakukan kegiatan komunikasi dengan berbagai entitas.[4]

Sistem Pendukung Keputusan juga merupakan Sistem berbasis komputer interaktif yang membantu dalam pengambilan keputusan dengan memanfaatkan data dan model untuk menyelesaikan masalah masalah yang tak terstruktur.[5]

\section{Decission Tree}

Decision tree atau pohon keputusan merupakan salah satu teknik klasifikasi. Decision tree adalah top-down pohon rekursif dari algoritma induksi, yang menggunakan ukuran seleksi atribut untuk memilih atribut yang diuji dengan pohon keputusan manusia dapat dengan mudah melihat hubungan antara faktor-faktor yang mempengaruhi suatu masalah.[6] Menurut Berry \& Linoff pohon keputusan adalah sebuah struktur yang dapat digunakan untuk membagi kumpulan data yang besar menjadi himpunan-himpunan record yang lebih kecil dengan menerapkan serangkaian aturan keputusan.[7]

\section{Algoritma C5.0}

Menurut Wijaya dkk. (2018 :193) algoritma C5.0 merupakan penyempurna dari algoritma C4.5 dan ID3 yang dibentuk oleh Ross Quinlan pada tahun 1987, yang khususnya diterapkan pada teknik decision tree.[8] Algoritma C5.0 adalah salah satu data mining yang khususnya diterapkan pada teknik decision tree. Dalam algoritma ini pemilihan atribut yang akan diproses menggunakan information gain. Memilih atribut untuk pemecah objek dalam beberapa kelas yang menghasilkan gain paling besar. Atribut dengan nilai information gain tertinggi akan dipilih sebagai parent untuk node selanjutnya.[9]

Cara penyelesaiannya algoritma C5.0 dengan beberapa tahapan yaitu: 
1. Mempersiapkan Data Pengujian atau Training

2. Menentukan Kriteria dari Atribut Terpilih

3. Menghitung Nilai Entrophy dan Gain

Dari data yang sudah di reduksi dan dipilih atributnya kemudian menghitung nilai entrophy dan gain dari masing-masing atribut yang telah dipilih, berikut cara perhitungannya seperti rumus dibawah ini:

Menghitung nilai entrophy total dengan rumus:

$$
\text { Entrophy }(S)=\sum_{i=1}^{m}-p i \times \log _{2}(p i)
$$

Keterangan:

S : Himpunan kasus atau atribut

$\mathrm{m} \quad$ : Jumlah partisi $S$

pi : Jumlah proporsi dari total atribut $(\mathrm{Si})$ terhadap total keseluruhan (S)

Kemudian hitung nilai gain setiap atribut dengan rumus:

$$
\operatorname{Gain}(S, A)=E(S)-\sum_{i=1}^{m} \frac{|S i|}{S} \times E(S i)
$$

Keterangan:

E (S) : Entropy Semesta atau Entropy Total

E (Si): Entropy Atribut

A : Atribut

$\mathrm{m}$ : Jumlah sample atribut A

$\mathrm{Si}$ : Jumlah kasus total atribut (pada partisi ke-i)

S : Jumlah total data keseluruhan

\section{Membuat Pohon Keputusan (Tree)}

Setelah dilakukan perhitungan nilai entrophy dan gain maka dapat dibuat pohon keputusan dengan node akar berdasrkan urutan gain yang memiliki nilai tertinggi.

\section{Menentukan Confusion Matrix}

Confix Matrix merupakan metode yang digunakan untuk menghasilkan atau mengukur nilai tingkat keakurasian, serta laju error.
Akurasi menyatakan jumlah data yang telah diklasifikasikan benar setelah dilakukan proses pengujian.[6]

Tabel 1. Tabel Confusion Matrix

\begin{tabular}{|c|c|c|}
\hline \multicolumn{3}{|c|}{ Diidentifikasi dengan Algoritma C5.0 } \\
\hline $\begin{array}{c}\text { Diidentifikasi Keputusan } \\
\text { Data Uji Coba }\end{array}$ & Ya & Tidak \\
\hline Ya & True positives & False negatives \\
\hline Tidak & False positives & True negatives \\
\hline
\end{tabular}

6. Menentukan akurasi dan laju error data

Nilai akurasi menggambarkan tingkat keakuratan identifikasi data yang dilakukan oleh algoritma C5.0.

$$
\text { Akurasi }=\frac{T P+T N}{T P+F N+F P+T N} \times 100 \%
$$

Nilai laju error menggambarkan tingkat kesalahan identifikasi data yang dilakukan oleh algoritma C5.0.

Laju error $=\frac{\text { Jumlah data diidentifikasi salah }}{\text { Jumlah seluruh data }} \times 100 \%$

\section{Android Studio}

Android studio adalah IDE (Integrated Development Environment) resmi untuk pengembangan aplikasi Android dan bersifat open source atau gratis. Peluncuran Android studio diumumkan oleh Google pada 16 mei 2013 pada Event Google I/O Conference tahun 2013. Sejak saat itu Android studio mengantikan Eclipse sebagai IDE resmi untuk mengembangkan aplikasi-nya.[10]

\section{Unified Modeling Language (UML)}

Menurut Windu dan Grace (2013) Unified Modeling Language (UML) adalah bahasa spesifikasi standar yang dipergunakan untuk mendokumentasikan, menspesifikasikan dan membanngun perangkat lunak. UML itu sendiri juga merupakan sebuah bahasa yang berdasarkan grafik atau gambar untuk memvisualisasi, menspesifikasikan, 
membangun, dan pendokumentasian dari sebuah sistem pengembangan software berbasis OO (Object-Oriented).[11]

\section{METODE}

Adapun metode pendekatan yang digunakan dalam penelitian ini menggunakan pendekatan kualitatif dengan case study research di PT. Sinergi Indo Prima. Metode ini digunakan agar data-data yang diperoleh valid dan reliable dapat dilakukan sebagai berikut:[12]

1. Observasi

Penulis melakukan pengamatan langsung pada perusahaan pelayanan jasa (Outsourcing) dalam hal ini melihat data-data calon tenaga kerja.

2. Wawancara

Penulis melakukan wawancara dengan

Human Resource Departmen (HRD)

PT. Sinergi Indo Prima Medan dengan masalah terkait penerimaan calon tenaga kerja outsourcing yang telah dilakukan selama perusahaan outsourcing didirikan.

3. Studi Pustaka

Penulis banyak mencari referensi dari berbagai sumber terpercaya dan melakukan tinjauan pustaka jurnal, buku, artikel karya ilmiah, sumber informasi lainnya dari internet yang berkaitan dengan Sistem Pendukung Keputusan (SPK) dan Algoritma C5.0.

Metode pengembangan sistem yang digunakan dalam penelitian ini ialah menggunakan metode Rapid Application Development (RAD) metode ini digunakan karena tahap-tahapannya terstruktur, waktu pengerjaan yang relatif singkat yang menekankan pada siklus yang pendek.[13]

\section{A. Requiretment Planning}

Pengumpulan data umum perusahaan dan data calon tenaga kerja satpam, staf administrasi, buruh, sales promotor, supir dan jasa kebersihan dengan melakukan pengelompokkan terhadap data yang diperoleh kemudian penulis melakukan analisis terhadap sistem berjalan yang ada di perusahaan PT. Sinergi Indo Prima data calon tenaga kerja.

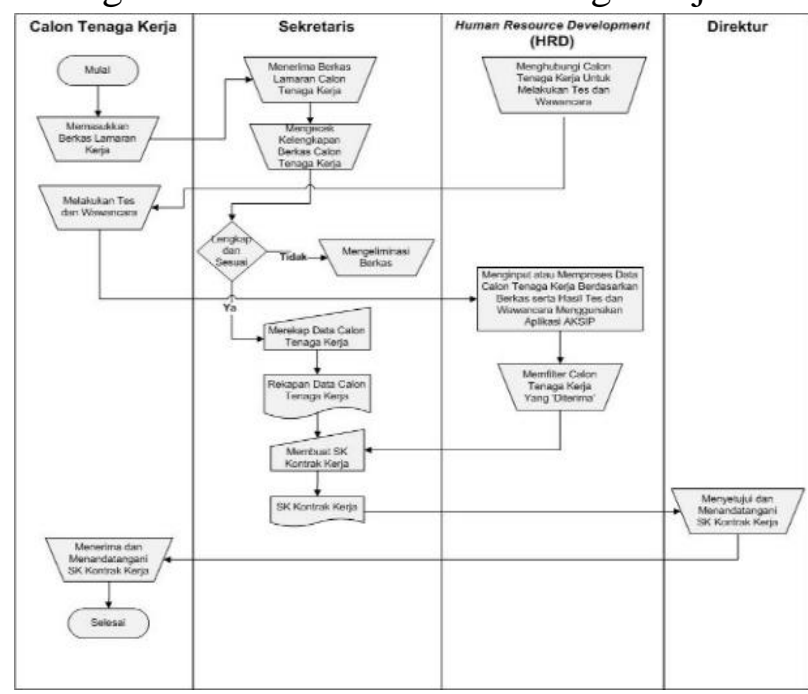

Gambar 1. Flowmap Sistem Usulan

\section{B. Workshop Design}

\section{Use Case Diagram}

Use case merupakan sebuah teknik yang digunakan dalam pengembangan sebuah software atau sistem informasi untuk merangkap kebutuhan fungsional dari sistem yang bersangkutan dijelaskan hanya ada satu actor yaitu seorang HRD yang dapat mengoperasikan aplikasi AKSIP.

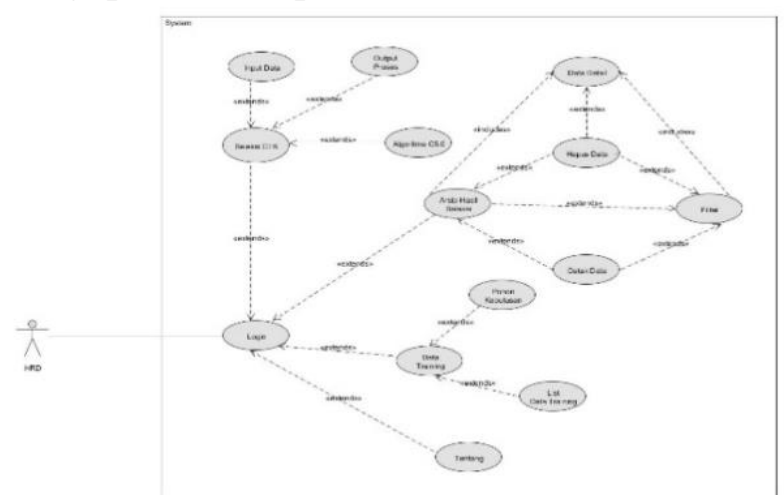

Gambar 2. Use Case Seleksi Calon Tenaga Kerja 


\section{Activity Diagram}

Diagram activity adalah sesuatu yang menggambarkan berbagai aliran proses atau aktivitas dalam suatu sistem yang sedang dirancang, bagaimana masing - masing fase atau alir berawal, decision yang mungkin terjadi dan bagaimana setiap fase berakhir, terlihat serangkaian alir dari proses pengguna atau user terhadap sistem adapun action yang dipilih oleh user dari gambar dijelaskan seperti berikut:

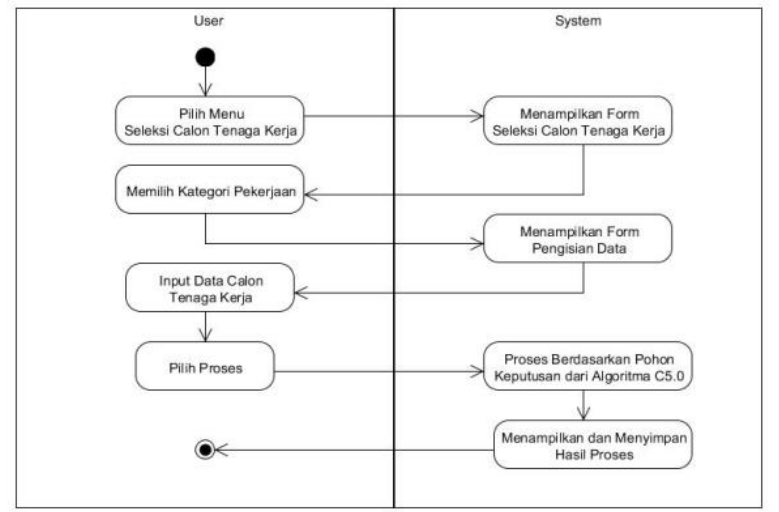

Gambar 3. Activity Seleksi Calon Tenaga Kerja

\section{Sequence Diagram}

Sequence diagram menurut (Shalahuddin dan Rosa, 2013) menggambarkan kelakuan suatu objek pada use case dengan mendeskripsikan waktu hidup suatu objek dan message yang dikirimkan dan diterima antar objek.[14]

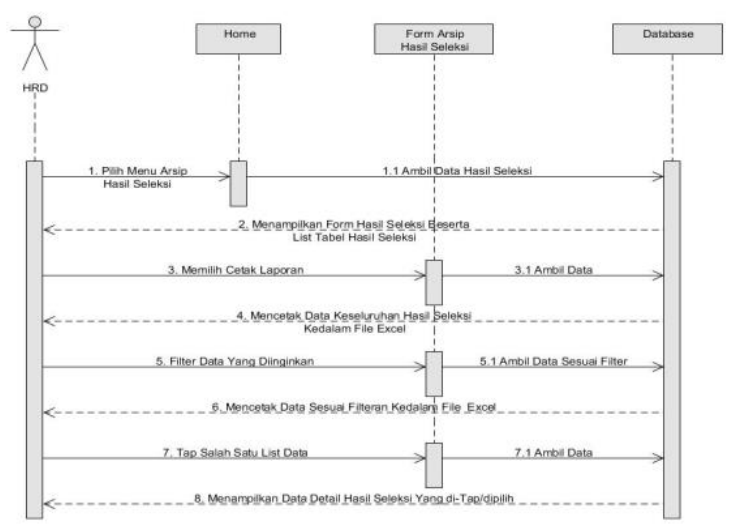

Gambar 4. Sequence Melihat dan Mencetak Data Calon Tenaga Kerja

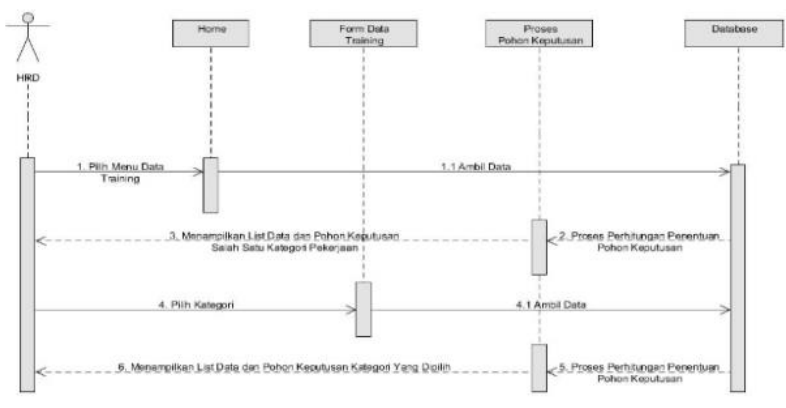

Gambar 5. Sequence Melihat Data Training Calon Tenaga Kerja

\section{Class Diagram}

Class diagram menggambarkan struktur dan deskripsi class, package dan object beserta hubungan satu sama lain seperti containment, pewarisan, asosiasi dan lain-lain.[2] Human Resource Departmen (HRD) yang mengendalikan atau mengelola sistem penerimaan calon tenaga kerja outsourcing.

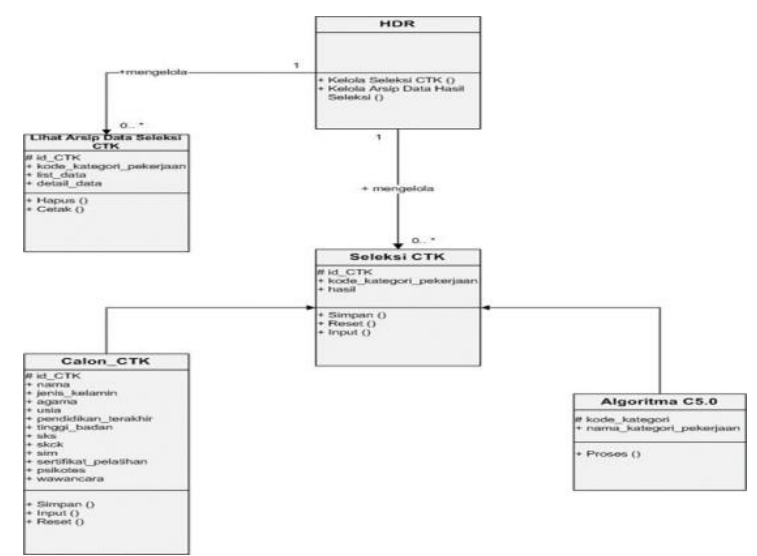

Gambar 6. Class Diagram Sistem Seleksi Data Calon Tenaga Kerja

\section{Implementation}

\section{Analisi Data}

Pada tahap ini sebanyak 200 data digunakan sebagai data data training dan uji coba pada masing - masing kategori pekerjaan yaitu satpam atau security, staf administrasi atau administration, buruh atau helper, promotor penjualanan atau sales promotion (SPG/SPB), supir atau driver, dan jasa kebersihan atau 
cleaning service kemudian dihitung dengan rumus dari algoritma C5.0.

Salah satu data training yang akan dilakukan perhitungan yaitu buruh/helper, cleaning service, sales promotion/SPG-SPB dengan 60 data training seperti tabel berikut:

Tabel 2. Tabel Data Training Buruh-CS-SPG/SPB

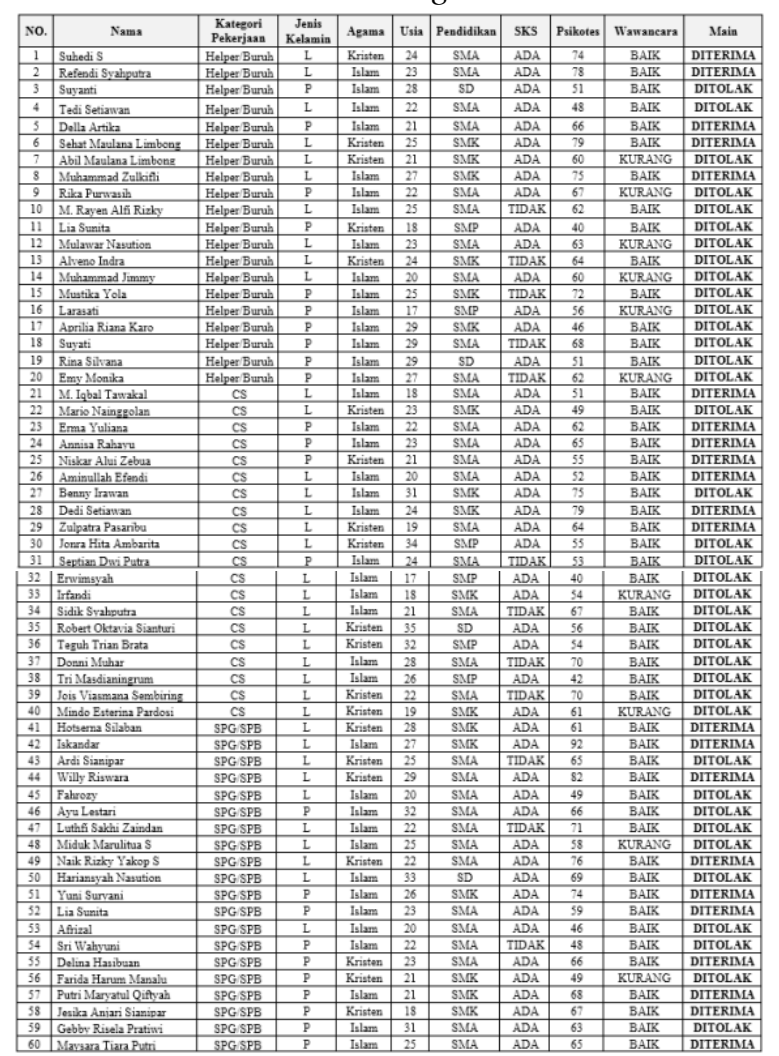

Selanjutnya dapat dilakukan perhitungan data dengan algoritma C5.0 langkah pertama dengan mencari entropy total kemudian dilanjutkan dengan mencari entropy dan gain dari setiap masing-masing atribut dengan perhitungan berikut:

\section{Entropy (Total Data)}

$=\left(-\left(\frac{22}{60}\right) \times \log _{2}\left(\frac{22}{60}\right)\right)+\left(-\left(\frac{38}{60}\right) \times \log _{2}\left(\frac{38}{60}\right)\right)=0,948078$

Tabel 3. Analisis Data Atribut Banyaknya Kejadian Nilai Entropy dan Gain

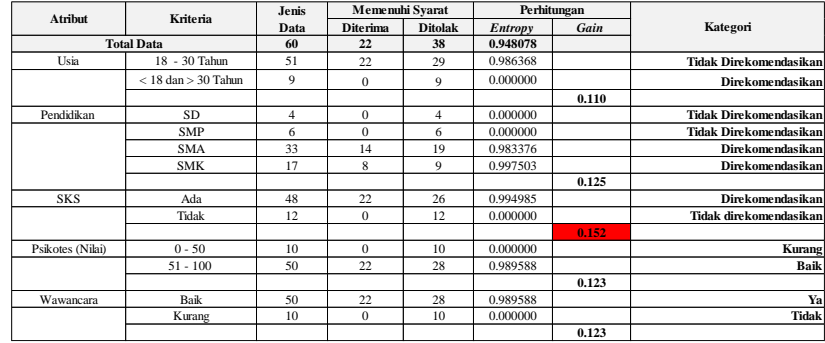

Contoh perhitungan lainnya:

Entropy (SKS "Ada") $=\left(-\left(\frac{22}{48}\right) \times \log _{2}\left(\frac{22}{48}\right)\right)+\left(-\left(\frac{26}{48}\right) \times \log _{2}\left(\frac{26}{48}\right)\right)=0,994985$

Entropy (SKS "Tidak")

$=\left(-\left(\frac{0}{12}\right) \times \log _{2}\left(\frac{0}{12}\right)\right)+\left(-\left(\frac{12}{12}\right) \times \log _{2}\left(\frac{12}{12}\right)\right)=0,00000$

Selanjutnya untuk menghitung nilai gain salah satunya dari atribut SKS buruh/helper, jasa kebersihan/cleaning service dan promotor/sales promotin (SPG/SPB) berikut ini:

$$
\begin{gathered}
\operatorname{Gain}(S K S)=0,948078-\left(\left(\frac{48}{60}\right) \times 0,994985+\left(\frac{12}{60}\right) \times 0,00000\right) \\
=0,152
\end{gathered}
$$

Selanjutnya dilakukan analisis data atau pemisahan data contohnya data calon tenaga kerja yang memiliki SKS ada dan yang tidak ada akan dieliminasi.

Tabel 4. Analisis Data Buruh - CS SPG/SPB

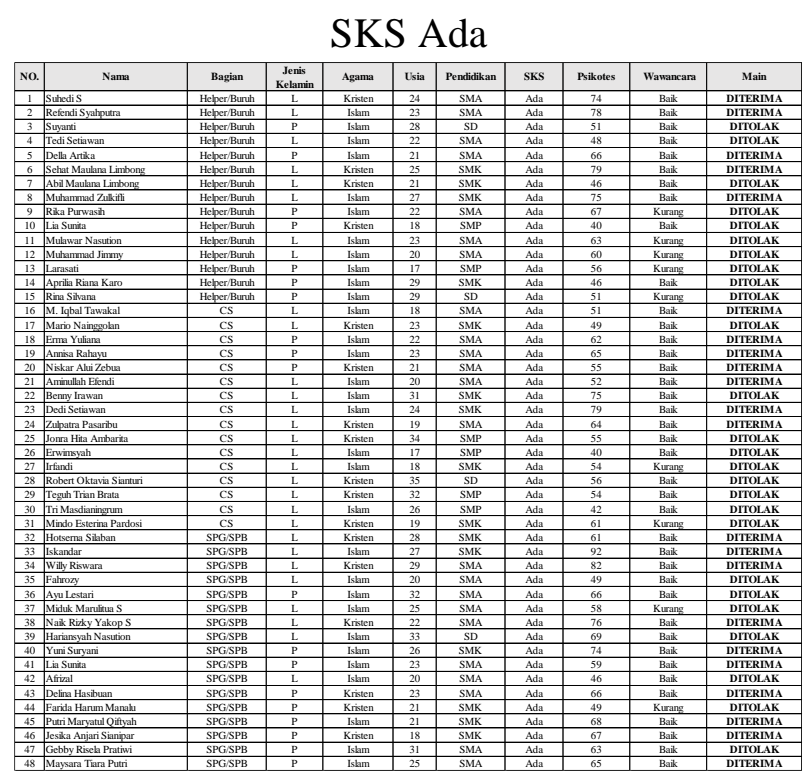


Kemudian dari data SKS "Ada" diatas dianalisis dan dihitung kembali nilai entropy total beserta nilai gain yang nantinya untuk dibuat menjadi node berikutnya berdasarkan nilai gain yang memiliki urutan tertinggi sampai akhir dari atribut yang memiliki nilai terendah.

Dari perhitungan entropy dan gain, maka didapatlah pohon keputusan pada masingmasing kategori pekerjaan dibuat berdasarkan urutan gain dari atribut yang memiliki nilai gain tertinggi.

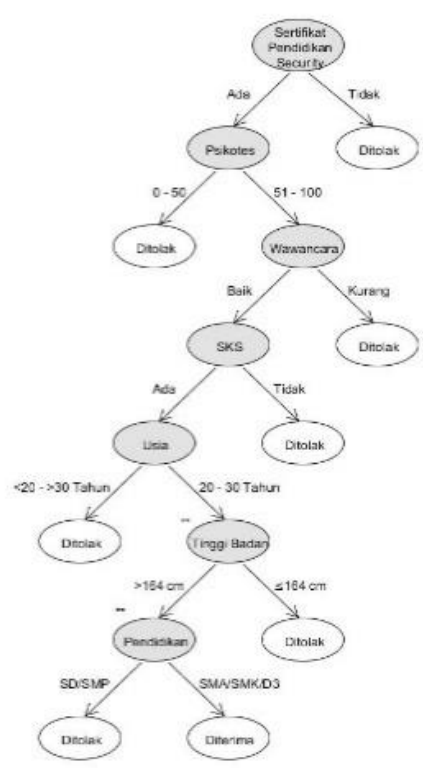

Gambar 7. Pohon Keputusan Pekerjaan Satpam

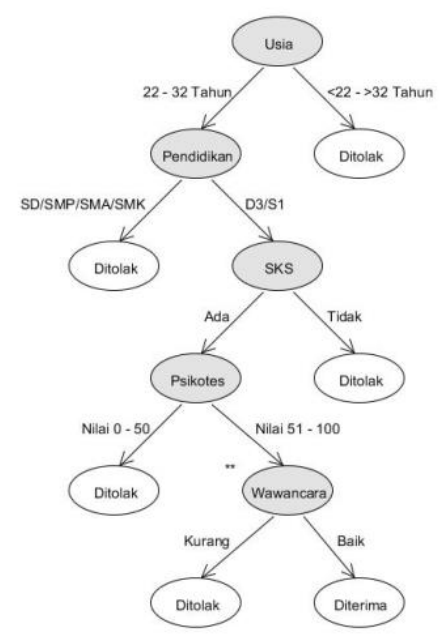

Gambar 8. Pohon Keputusan Pekerjaan Staf Administrasi

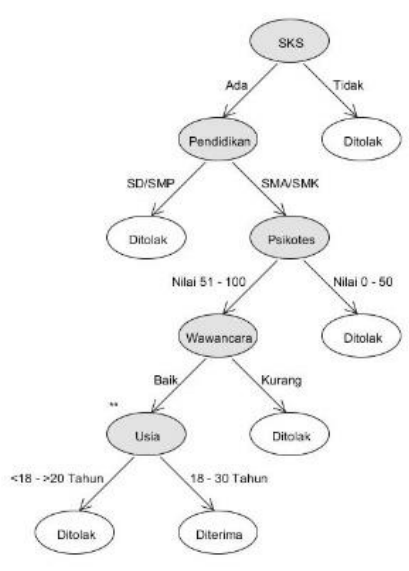

Gambar 9. Pohon Keputusan Pekerjaan Buruh/helper-CS-SPG/SPB

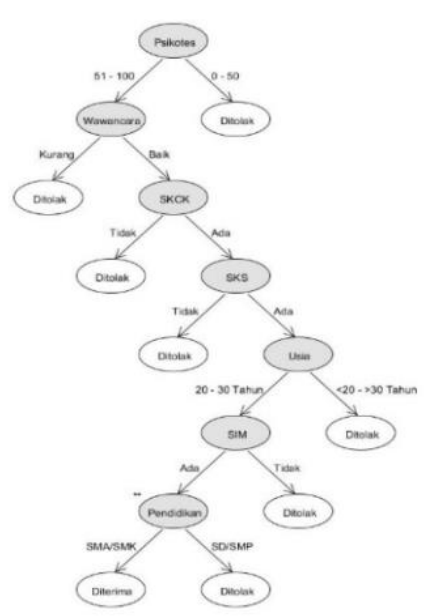

Gambar 10. Pohon Keputusan Pekerjaan Supir

\section{Antarmuka Sistem}

Adapun implementasi antarmuka yang ada pada aplikasi AKSIP yang telah dibangun seperti berikut:

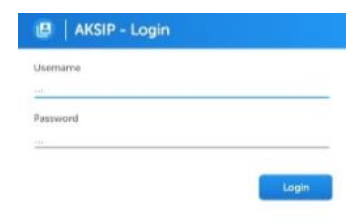

Gambar 11. Tampilan Form Login 


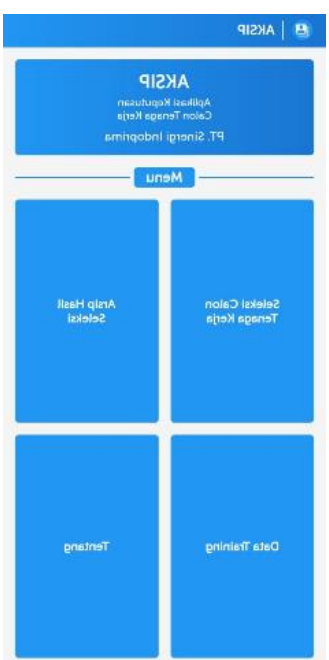

Gambar 12. Tampilan Form Menu

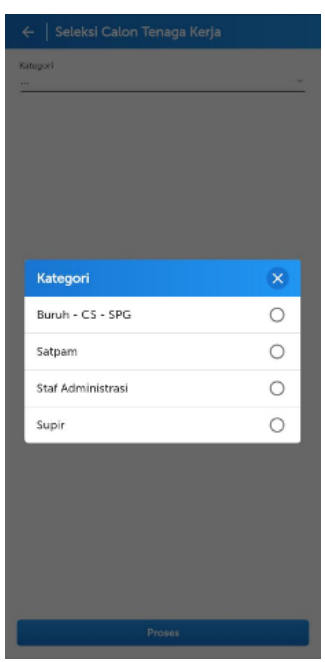

Gambar 13. Tampilan Form Kategori Seleksi Calon Tenaga Kerja

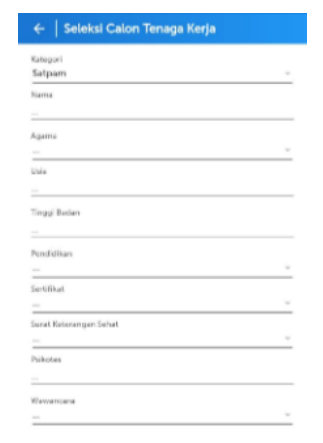

Gambar 14. Tampilan Form Kategori Satpam

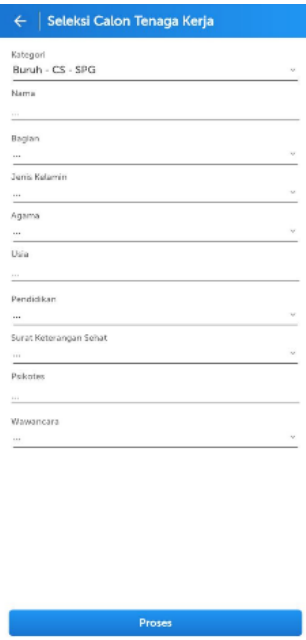

Gambar 15. Tampilan Form Kategori Kategori Buruh/helper - CS - SPG/SPB

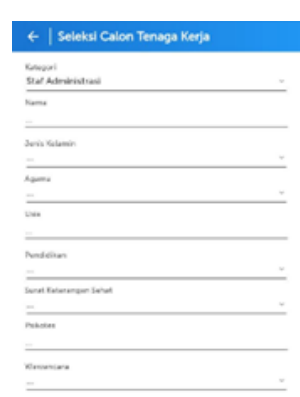

Gambar 16. Tampilan Form Kategori Staf Administrasi

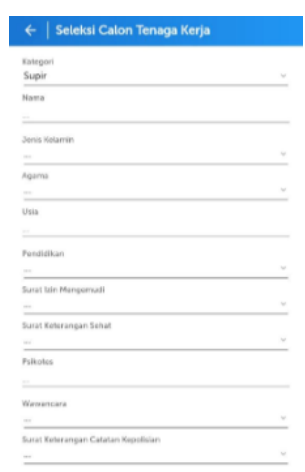

Gambar 17. Tampilan Form Kategori Supir 


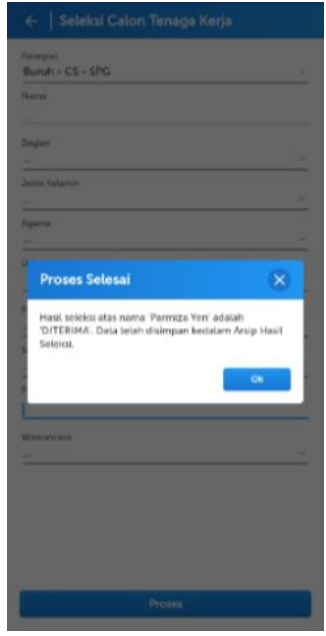

Gambar 18. Tampilan Form Proses Hasil Seleksi Calon Tenaga Kerja

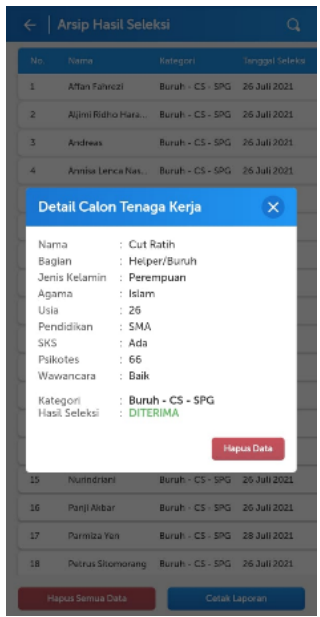

Gambar 19. Tampilan Form Kategori Arsip Detail Hasil Seleksi Calon Tenaga Kerja

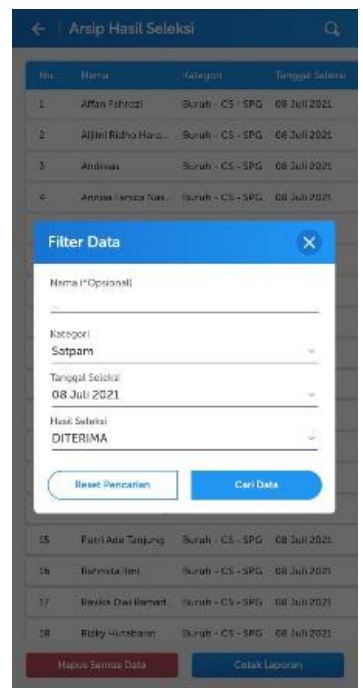

Gambar 20. Tampilan Form Arsip Filter Data Calon Tenaga Kerja

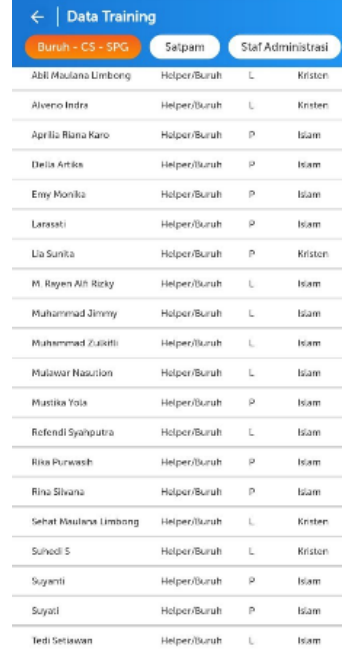

Gambar 21. Tampilan Form Data Training

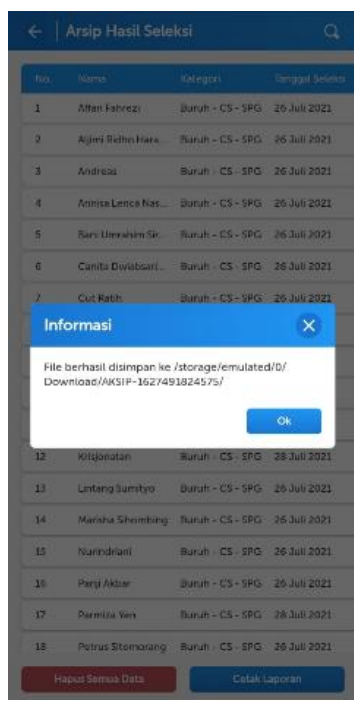

Gambar 22. Tampilan Form Arsip Cetak Laporan Hasil Seleksi CTK

\section{HASIL}

Setelah dilakukan pengujian oleh aplikasi AKSIP sebanyak 50 data uji coba dari masingmasing kategori pekerjaan maka diperoleh hasil pengujian beserta pembahasan dari proses seleksi calon tenaga kerja Outsourcing berikut ini:

Tabel 5. Hasil Pengujian Data Uji Satpam

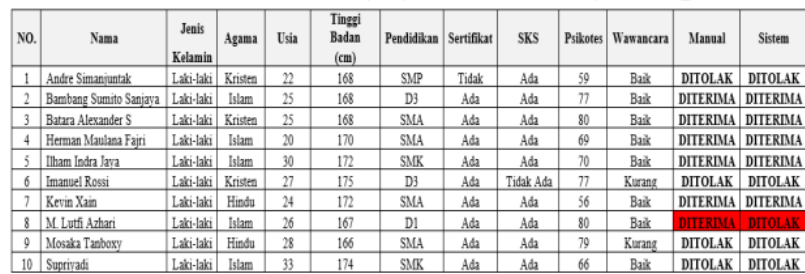


Tabel 6. Hasil Pengujian Data Uji

Buruh/helper - CS - SPG/SPB

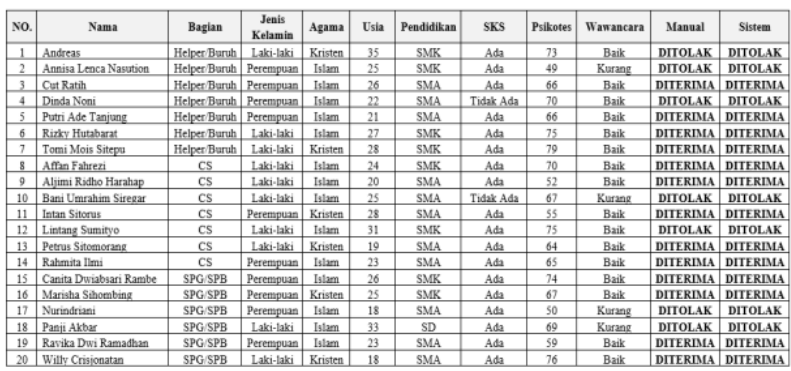

Tabel 7. Hasil Pengujian Data Uji Staf Administrasi

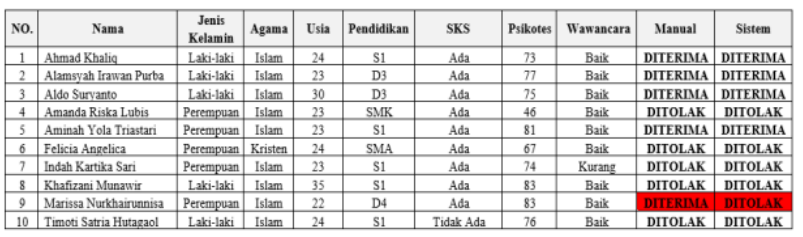

Tabel 8. Hasil Pengujian Data Uji Supir

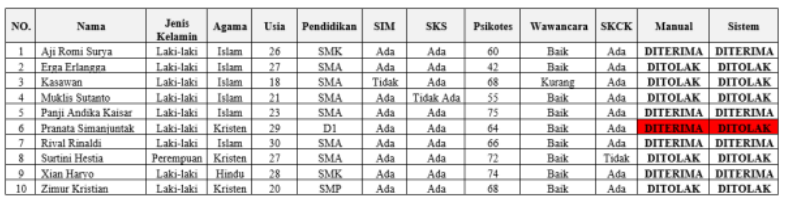

Berdasarkan kesulurahn data uji dari 6 (enam) kategori pekerjaan, maka diperoleh Confusion Matrix seluruh data uji diidentifikasi manual serta identifikasi dengan algoritma C5.0 adalah sebagai berikut:

Tabel 9. Confusion Matrix Seluruh Data Uji

\begin{tabular}{|c|c|c|}
\hline \multicolumn{3}{|c|}{ Diidentifikasi dengan Algoritma C5.0 } \\
\hline $\begin{array}{c}\text { Diidentifikasi } \\
\text { Keputusan Data } \\
\text { Uji Coba }\end{array}$ & $\begin{array}{c}\text { Ya } \\
\text { (Diterima) }\end{array}$ & $\begin{array}{c}\text { Tidak } \\
\text { (Ditolak) }\end{array}$ \\
\hline Ya & 25 & 3 \\
\hline Tidak (Ditolak) & 0 & 22 \\
\hline
\end{tabular}

Keterangan:

a. Berdasarkan identifikasi yang dilakukan secara manual dinyatakan "Ya" dan identifikasi yang dilakukan menggunakan algoritma C5.0 juga menyatakan "Ya" adalah sebanyak 25 data.

b. Berdasarkan identifikasi yang dilakukan secara manual dinyatakan "Ya", namun identifikasi yang dilakukan menggunakan algoritma C5.0 menyatakan "Tidak" adalah sebanyak 3 data.

c. Berdasarkan identifikasi yang dilakukan secara manual dinyatakan "Tidak", namun identifikasi yang dilakukan menggunakan algoritma C5.0 menyatakan "Ya" adalah sebanyak 0 data.

d. Berdasarkan identifikasi yang dilakukan secara manual dinyatakan "Tidak" dan identifikasi yang dilakukan menggunakan algoritma C5.0 juga menyatakan "Tidak" adalah sebanyak 22 data.

Kemudian didapatlah akurasi dan laju error data untuk semua kategori pekerjaan calon tenaga kerja outsourcing sebagai berikut ini:

$$
\begin{aligned}
\text { Akurasi }= & \frac{25+22}{25+3+0+22} \times 100 \% \\
=\frac{47}{50} \times 100 \% & =94 \%
\end{aligned}
$$

Laju error $=\frac{3}{50} \times 100 \%=6 \%$

Jadi, berdasarkan perhitungan dari keseluruhan data uji semua kategori pekerjaan outsourcing diatas dengan menggunakan aplikasi AKSIP maka diperoleh persentasi akurasi sistem sebesar 94\% dan laju error sebesar 6\%,

\section{KESIMPULAN}

Berdasarkan penelitian yang telah dilakukan oleh peneliti, maka diperoleh beberapa kesimpulan yaitu:

1. Dengan menggunakan Aplikasi AKSIP Human Resources Development (HRD) lebih mudah dalam mengambil sebuah keputusan untuk calon tenaga kerja dari masing-masing kategori pekerjaan sehingga membuat pekerjaan menjadi efektif dan efisien.

2. Dengan menggunakan algoritma C5.0 maka terbentuklah pohon keputusan yang menentukan urutan atribut yang menjadi 
prioritas suatu keputusan dimana jika salah satu atribut tidak terpenuhi maka atribut lainnya tidak perlu diproses sehingga mempersingkat waktu proses sistem.

3. Semakin banyak data training dan semakin bervariasi isi atribut maka akursi sistem tersebut akan semakin baik.

4. Dengan Algoritma C5.0 maka juga akan diperoleh persentasi akurasi dan laju error kesesuaian antara proses yang dilakukan secara manual yang sebelumnya masih menggunakan filter data dari Microsoft Excel untuk penentuan keputusan penerimaan data calon tenaga kerja dengan proses yang dilakukan oleh aplikasi AKSIP hasil keputusan penerimaan calon tenaga kerja menjadi lebih sistematis dan mudah dalam proses seleksi penerimaan data calon tenaga kerja yang diterima dan ditolak dengan hasil secara realtime.

\section{SARAN}

Berdasarkan penelitian yang telah dilakukan penulis menguraikan beberapa saran untuk pembaca dan peneliti selanjutnya yaitu:

1. Dalam penelitian ini aplikasi hanya dilakukan secara offline, diharapkan untuk selanjutnya dapat dilakukan secara online.

2. Data training yang diperoleh sedikit kurang bervariasi sehingga kurang maksimal, diharapakan untuk penelitian selanjutnya lebih menggunakan banyak data training dan lebih bervariasi.

\section{DAFTAR PUSTAKA}

[1] K. W. Ap, "Implementasi Algoritma C4 .5 untuk Perekrutan Karyawan Berbasis Android ( Studi Kasus: Blackberry Service Center Medan )," 2018.

[2] Samsudin, "Penentuan Penerimaan Remunerasi Dosen Dengan Rule Based Reasoning," Medan, 2018. [Online]. Available: file:///E:/SKRIPSI - New File/S K R I P S I/SKRIPSI/Daftar Referensi Proposal Skripsi/Laporan Penelitian Samsudin (1).pdf.

[3] Samsudin, "Optimalisasi Penerimaan Remunerasi Dosen Menggunakan Metode Rule Base Reasoning," Kumpul.
J. Ilmu Komput., vol. 06, no. 3, pp. 224 240, 2019.

[4] L. M. Yulyantari and I. P. Wijaya, Manajemen Model Pada Sistem Pendukung Keputusan. Yogyakarta: CV. Andi Offset, 2019.

[5] A. Ikhwan, S. B. Siagian, S. Mawaddah, M. Annisah, and S. Informasi, "Penerima Beras Raskin Dengan Metode Fuzzy," vol. 9, no. 2, pp. 457-463, 2019.

[6] I. M. Sudarma, "Implementasi Algoritma C5 . 0 pada Penilaian," Maj. Ilm. Teknol. Elektro, vol. 17, no. 3, pp. 1-6, 2018.

[7] E. T. Kusrini, Luthfi, Algoritma Data Mining. Yogyakarta: CV. Andi Offset, 2009.

[8] A. C. Wijaya, N. A. Hasibuan, and P. Ramadhani, "Implementasi Algoritma C5 . 0 Dalam Klasifikasi Pendapatan Masyarakat ( Studi Kasus : Kelurahan Mesjid Kecamatan Medan Kota )," Inf. dan Teknol. Ilm., vol. 13, pp. 192-198, 2018.

[9] C. Hutabarat, "Penerapan Data Mining Untuk Memprediksi Permintaan Produk Kartu Perdana Internet Menggunakan Algoritma C5.0 (Studi Kasus: Vidha Ponsel)," J. Pelita Inform., vol. 17, no. 2, pp. 168-173, 2018.

[10] J. Andi, "Pembangunan Aplikasi Child Tracker Berbasis Assisted - Global Positioning System ( A-GPS ) Dengan Platform Android," J. Ilm. Komput. dan Inform., vol. 1, no. 1, pp. 1-8, 2015, [Online].

Available: elib.unikom.ac.id/download.php?id=300 375.

[11] Suendri, "Implementasi Diagram UML (Unified Modelling Language) Pada Perancangan Sistem Informasi Remunerasi Dosen Dengan Database Oracle (Studi Kasus: UIN Sumatera Utara Medan)," vol. 6341, no. November, pp. 1-9, 2018.

[12] M. H. Fakhriza and Ispandi, "Sistem Penunjang Keputusan Kenaikan Jabatan Pada PT.Metraplasa," Gerbang, vol. 8, no. 1, pp. 73-79, 2018.

[13] J. R. Sagala, "Model Rapid Application 
Development $\quad(\mathrm{Rad}) \quad$ Dalam

Pengembangan Sistem Informasi

Penjadwalan Belajar Mengajar," $J$.

Mantik Penusa, vol. 2, no. 1, pp. 87-90, 2018.

[14] W. Aprianti and U. Maliha, "Sistem Informasi Kepadatan Penduduk Kelurahan Atau Desa Studi Kasus Pada Kecamatan Bati-Bati," vol. 2, no. 2013, pp. 21-28, 2016. 